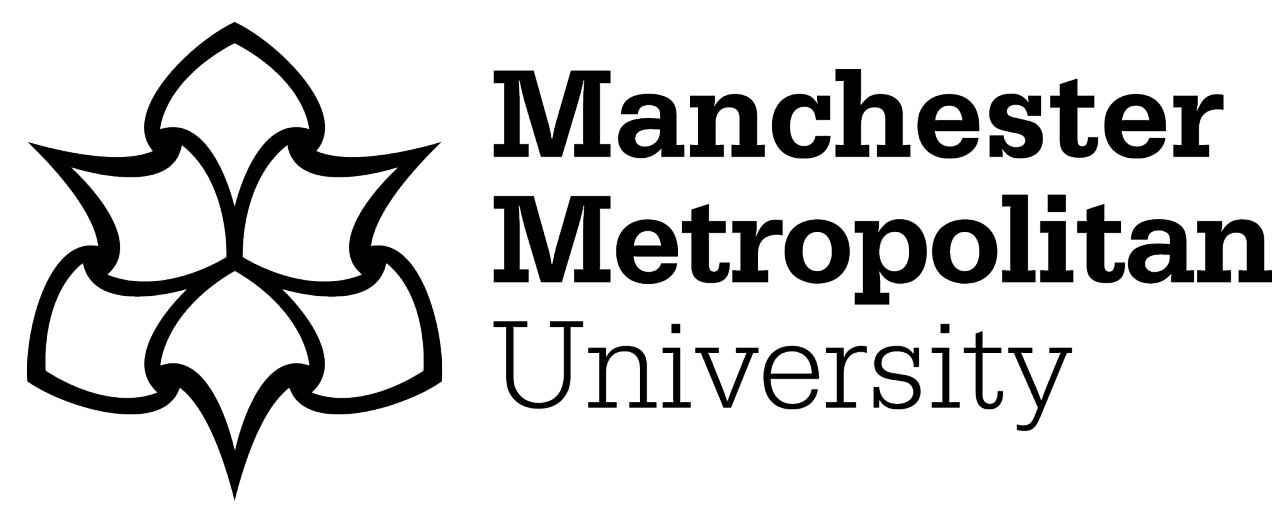

Lalor, Kay ORCID logoORCID: https://orcid.org/0000-0002-3265-7264 (2020) Queer Legacies of Colonialism. In: The Queer Outside in Law: Recognising LGBTIQ People in the United Kingdom. Palgrave. ISBN 978-3030-48830-7

Downloaded from: https://e-space.mmu.ac.uk/625083/

Version: Accepted Version

Publisher: Palgrave

Please cite the published version 


\section{Queer Legacies of Colonialism}

\section{Introduction}

The ongoing effects of the British Empire's criminalisation of sodomy in its colonies have received considerable legal, political and public attention. ${ }^{1}$ Less well attended however, is the related issue of the queer legacy of colonialism in UK law. It is this legacy that this chapter addresses. The chapter argues that the approach of British political and legal actors to the UK's colonial history is inherently paradoxical. Most notably, while there is some acknowledgement of the colonial past, there is a refusal to fully account for the ongoing effects of this past in the present, or for how geopolitical relations that maintain dynamics of 'here' and 'there' or 'inside and 'outside' reduce the possibility of meaningful action. In contrast, a queer approach to this colonial legacy is one that confronts these paradoxes and in so doing, prepares for the possibility of radical and overarching structural change.

To trace the queer legacy of colonialism in UK law, it is important to distinguish between the colonial era, as an historical period marked by European territorial acquisition ${ }^{2}$; imperialism, as the operation of power beyond state borders that may or may not involve territorial conquest $^{3}$; and coloniality as the ongoing effects of colonial history and of past and present operation of imperial power, or the "continuity of colonial forms of domination after the end of colonial administrations' ${ }^{4}$ Equally important is the positioning of queerness in relation to colonialism, coloniality and imperialism. 'Queer' here is not a catch all term for the

\footnotetext{
${ }^{1}$ Pippa Crerar, "Theresa May Says She Deeply Regrets Britain's Legacy of Anti-Gay Laws," The Guardian 17 April 2018 ; Alok Gupta, "This Alien Legacy the Origins of "Sodomy" Laws in British Colonialism," ed. Human Rights Watch (2008); Michael Kirby, "The Sodomy Offence: England's Least Lovely Criminal Law Export?," in Human Rights, Sexual Orientation and Gender Identity in the Commonwealth: Struggles for Decriminalisation and Change, ed. Corinne Lennox and Matthew Waites (Institute of Commonwealth Studies, 2013).

${ }^{2}$ Antony Anghie, Imperialism, Sovereignty and the Making of International Law (Cambridge: Cambridge University Press, 2007). p.11

${ }^{3}$ Ibid

${ }^{4}$ Ramón Grosfoguel, "The Epistemic Decolonial Turn," Cultural Studies 21, no. 2-3 (2007). p.219
} 
LGBTQIAA $+{ }^{5}$ community, nor is it simply a designation of non-normative identities or behaviours. Instead, following Colebrook, conditions of the queer are those which expose how 'the normal is achieved, produced, effected and also, therefore exposed as contingent, constituted and open to change'. ${ }^{6}$ Queerness is not simply about disrupting norms or categories of identity. It requires the repetition of previously unquestioned categories, norms, 'doxa' and assumptions, in new forms that challenge the "laziness of common sense ${ }^{7}$ and explore the unacknowledged potentialities contained within. Thus the queer, postcolonial and spatiotemporal analysis in this chapter seeks to expose how colonially produced hierarchies and inequalities exist in the present and limit possibilities for future action. This approach views 'inside' and 'outside' in space, time and law as unfixed, but structurally interdependent, and seeks to think how these structurally interdependent relations could configure new possibilities for action.

The chapter first considers how the queer legacy of colonialism must necessarily contend with coloniality - or its denial - and the legal implications of this. It then traces one instance of how this manifests through a close analysis of a House of Commons backbench debate on 'Global LGBT Rights'. Spatio-temporal irregularities within the debate are used to identify the presence of paradox at the heart of UK approaches to LGBT rights. The final section of the chapter uses Deleuzian scholarship of paradox to analyse how dichotomies of space, time, identity and law, that developed from the colonial encounter continue to structure and limit UK approaches to Global LGBT rights. For Deleuze, paradoxes are simultaneously moments of impasse and moments when our assumptions and axioms are revealed as limited and lacking. This revelation demands a re-working of those assumptions, opening up creative and radical

\footnotetext{
${ }^{5}$ A variety of abbreviations - LGBT, LGBTI, LGBTQI among others - are used in the literature. In this chapter, I use the formulation that is most appropriate to the point under discussion.

${ }^{6}$ Claire Colebrook, "On the Very Possibility of Queer Theory," in Deleuze and Queer Theory, ed. Chrysanthi Nigianni and Merl Storr (Edinburgh: Edinburgh University Press, 2009). p.21

${ }^{7}$ Claire Colebrook "Queer Vitalism," New Formations 68 (2010).
} 
moments of change. As such, Deleuzian paradox aligns closely with Colebrook's approach to queerness. The key impasse with which this chapter engages is the refusal, or inability, to fully acknowledge the ongoing effects of coloniality within British law and politics. This refusal results in the repetition of well-meaning expressions of support for SOGI communities, but limits the field of possibilities for meaningful or radical action. Indeed, a full engagement with the paradox of the queer legacy of colonialism in UK law would demand radical, structural changes that would go far beyond the current parameters of 'Global LGBT Rights'

\section{Temporalities of Coloniality and Law}

Attentiveness to coloniality reveals how 'habits of imperial engagement surround ${ }^{\text {, }}{ }^{8}$ far beyond the end of the colonial era as an historical period. This is the both for former colonies and for former colonial powers whose material, political and legal realities are shaped by the ongoing presence of coloniality.

A full accounting of the effects of all aspects of British colonialism is beyond the scope of this chapter, but it is important to note the extent to which the colonial 'civilizing mission', based on dichotomies of cultural difference, underpinned and justified imperial violence ${ }^{9}$, the transfer of resources and wealth from colonies to colonisers ${ }^{10}$, and the destruction of the philosophical and ontological systems of those who were colonised. ${ }^{11}$ Significantly, law played a central role in British colonial expansion and the ongoing legacy of British legal re-ordering can be found in contemporary domestic and international legal orders. ${ }^{12}$ With regards SOGI (sexual orientation and gender identity), in 2018, Prime Minister Theresa May expressed 'deep regret'

\footnotetext{
${ }^{8}$ Lauren Benton and Lisa Ford, Rage for Order the British Empire and the Origins of International Law, 1800-1850 (Cambridge, MA.: Harvard University Press, 2016). p192

${ }^{9}$ Anghie, Imperialism, Sovereignty and the Making of International Law p.3

${ }^{10}$ Aditya Mukherjee, "Empire: How Colonial India Made Modern Britain," Economic and Political Weekly 45, no. 50 (2010).

${ }^{11}$ Raewyn Connell, Southern Theory (Cambridge: Polity, 2007);

${ }^{12}$ Benton and Ford, Rage for Order; Anghie, Imperialism, Sovereignty and the Making of International Law 
for the British imperial role in perpetuating homophobic legislation. ${ }^{13}$ Criminalisation of 'offences against the order of nature' were developed in legal instruments such as Macaulay's Penal Code in India and the Griffiths Penal Code in Queensland. ${ }^{14}$ These became templates for legal frameworks elsewhere in the empire. ${ }^{15}$

A number of different elements of the ongoing effects of empire are significant to the analysis undertaken in this chapter. First is the underlying logics of coloniality: the ontological divide between the European self and the racialized, colonial other. ${ }^{16}$ Second are the forms of knowledge, knowledge production, action and law that grew from this foundational split - the structural violences of coloniality grounded in identities of civilised/uncivilised, self/other, centre/periphery that persist in the present. ${ }^{17}$ Related to this is the extent to which modern, racialized, middle-class identity and domestic practices were produced through colonial logics. ${ }^{18}$ Finally, as TWAIL (Third World Approaches to International Law) scholars have demonstrated, key legal structures - including modern statehood and sovereignty - emerged from the colonial encounter. ${ }^{19}$

Even with the persistence of imperial legal forms and the ongoing debates about the effect of colonialism and decolonialism on British society and culture ${ }^{20}$, there remains a relative

\footnotetext{
${ }^{13}$ Crerar, "Theresa May Says She Deeply Regrets Britain's Legacy of Anti-Gay Laws". It is important not to flatten out the specifics of how colonial forms of violence and control manifested in different locations. The existence of the same law in different states does not mean that the law was equally enforced either during the colonial era or currently. Nor does it mean that all precolonial societies were equally tolerant or (intolerant) of behaviours or identities beyond a heterosexual matrix.

${ }^{14}$ Kirby, "The Sodomy Offence"

${ }^{15}$ Ibid

${ }^{16}$ Grosfoguel, "The Epistemic Decolonial Turn,"; Walter D. Mignolo, "Decoloniality and Phenomenology: The Geopolitics of Knowing and Epistemic/Ontological Colonial Differences.," The Journal of Speculative Philosophy 32, no. 3 (2018).

17 Anghie, Imperialism, Sovereignty and the Making of International Law; Raewyn Connell, Southern Theory; Walter D. Mignolo, "Global Coloniality and the World Disorder: Decoloniality after Decolonization and Dewesternization after the Cold War," World Public Forum "Dialogue of Civilizations" 2016, http://wpfdc.org/images/2016_blog/W.Mignolo_Decoloniality_after_Decolonization_Dewesternization_after_the_Cold_Wa r.pdf.

${ }_{18}$ Anne McClintock, Imperial Leather: Race, Gender and Sexuality in the Colonial Contest (London: Routledge, 1995). p.5

${ }^{19}$ Anghie, Imperialism, Sovereignty and the Making of International Law; Ikechi Mgbeoji, "The Civilised Self and the Barbaric Other: Imperial Delusions of Order and the Challenges of Human Security," Third World Quarterly 27, no. 5 (2006).

${ }^{20}$ Stephen Howe, "Internal Decolonization? British Politics since Thatcher as Post-Colonial Trauma," Twentieth Century British History 14, no. 3 (2003); Richard Price, "One Big Thing: Britain, Its Empire, and Their Imperial Culture," Journal of British Studies 45, no. 3 (2006); Bernard Porter, "Further Thoughts on Imperial Absent-Mindedness," The Journal of Imperial and Commonwealth History 36, no. 1 (2008); Stuart Ward, ed. British Culture and the End of Empire (Manchester: Manchester University Press, 2001).
} 
'lightness' to the 'weight of empire' ${ }^{21}$ for the UK. British history is shaped by empire but it has a relative degree of control over how it acknowledges, represents and addresses its imperial past. $^{22}$ Empire is carefully positioned in British legal imaginaries, which means that the racialized hierarchies that persist in the post-colonial era, the peripheralisation of (racialized) groups and nations ${ }^{23}$, the axiomisation of certain foms of political and legal organisation is not a factor in sanitised 'regret' for imperial laws.

Ironically, the persistence of imperial legal structures does not mean that they are particularly stable. Both TWAIL and transnational legal literatures have emphasised the precarity of current international legal orderings. ${ }^{24}$ Whether it be through 'legal fragmentation' and the coexistence of a multiplicity of legal orders ${ }^{25}$, the failure of traditional legal orders to fully grasp the complexity of transnational developments ${ }^{26}$, or through the operation of legal power by non or quasi-legal bodies, ${ }^{27}$ the role of the state as a legal actor is in a situation of transformation and flux. ${ }^{28}$ While the weight of empire and coloniality may be relatively 'light' in the UK, current conditions mean that structures of international law and power (many of which are products of the colonial era) are somewhat precarious. One effect of this is a loss of certainty, or as Zumbansen notes, 'institutional structures that we expect to provide guidance with regard to who has and who can effectively assume political responsibility and agency today become ever

\footnotetext{
${ }^{21}$ Alia Al-Saji, "SPEP Co-Director's Address: Hesitation as Philosophical Method-Travel Bans, Colonial Durations, and the Affective Weight of the Past," The Journal of Speculative Philosophy 32, no. 3 (2018); Frantz Fanon, Black Skin, White Masks (London: Pluto, 1986).

${ }^{22}$ Al-Saji, "Hesitation as Philosophical Method"; Priyamvada Gopal, "Redressing Anti-Imperial Amnesia," Race \& Class 57, no. 3 (2016).

${ }^{23}$ Grosfoguel, "The Epistemic Decolonial Turn"

24 See particularly Balakrishnan Rajagopal, "Counter-Hegemonic International Law: Rethinking Human Rights and Development as a Third World Strategy," Third World Quarterly 27, no. 5 (2006).

${ }^{25}$ Dana Burchardt, "Intertwinement of Legal Spaces in the Transnational Legal Sphere," Leiden Journal of International Law 30, no. 2 (2017).

${ }^{26}$ Luis Eslava, "Istanbul Vignettes: Observing the Everyday Operation of International Law," London Review of International Law 2, no. 1 (2014); Aihwa Ong, "(Re)Articulations of Citizenship," PS: Political Science and Politics 38, no. 4 (2005).

${ }^{27}$ Mark James and Guy Osborn, "The Olympics, Transnational Law and Legal Transplants: The International Olympic Committee, Ambush Marketing and Ticket Touting," Legal Studies 36, no. 1 (2016).

${ }^{28}$ Ralf Michaels, "Globalisation and Law: Law Beyond the State " in Law and Social Theory ed. Reza Banakar and Max Travers (Oxford: Hart, 2013).
} 
more volatile'. ${ }^{29}$ This volatility is experienced as loss: 'loss of being able to adequately depict, express and capture the complexity of the developments which engulf us'. ${ }^{30}$

It is important to note that the precarity of colonially produced frameworks of international law and state sovereignty manifests differentially - not all states are equally vulnerable to international legal and political changes ${ }^{31}$, nor are states necessarily singular entities - they fulfil a multiplicity of positions and roles. ${ }^{32}$ For the purposes of this chapter however, the tensions here outlined call into question state power and capacity to manage dichotomies of inside/outside. Contained within this is a challenge to strict, structural separations between transnational, international and domestic jurisdictions. ${ }^{33}$ This demonstrates the extent to which the forms that state power takes are historically produced and thus changeable or even vulnerable. Inside and outside of state borders, law or even culturally differentiated identities of self/other are not fixed positions; they are changing and changeable polarities that are formulated, enunciated and represented with varying degrees of success in different spatiotemporal locations.

This means that in the context of the queer legacy of colonialism in UK law, there is a fundamental instability at play: a simultaneous turning away from the 'unaddressed and unredressed imperial past ${ }^{34}$, even while products of that past inform norms of sovereignty, statehood national identity and authority. This occurs even as those norms are rapidly undermined by the increasing complexity of the international sphere within which the UK now

\footnotetext{
${ }^{29}$ Peer Zumbansen, "How, Where and for Whom? Interrogating Law's Forms, Locations and Purposes," in Legal Studies Research Paper Series, ed. Dayan Farias Picon (Kings College London Dickson Poon School of Law, 2016). p.6

${ }^{30}$ Ibid. While it beyond the scope of this chapter to deal with all manifestations of this sense of loss, there has been considerably analysis of the relationship between empire and Brexit. See Nadine El-Enany "Things Fall Apart: From Empire to Brexit Britain" IPR Blog, May 2nd 2017 http://blogs.bath.ac.uk/iprblog/2017/05/02/things-fall-apart-from-empire-to-brexit-britain/ ${ }^{31}$ Luis Eslava, Local Space, Global Life: The Everyday Operation of International Law and Development (Cambridge: Cambridge University Press, 2015);

${ }^{32}$ Paisley Currah, "The State," TSQ: Transgender Studies Quarterly 1, no. 1-2 (2014).

${ }^{33}$ Eslava, Local Space, Global Life; Carol J. Greenhouse, "Nationalizing the Local: Comparative Notes on the Recent Restructuring of Political Space," in Human Rights in the 'War on Terror', ed. Richard Ashby Wilson (Cambridge: Cambridge University Press, 2005); Aihwa Ong, "(Re)Articulations of Citizenship," PS: Political Science and Politics 38, no. 4 (Oct 2005) (2005); Zumbansen, "How, Where and for Whom? Interrogating Law's Forms, Locations and Purposes,"

${ }^{34}$ El-Enany, "Things Fall Apart"
} 
exists. The legacy of empire therefore encompasses a complex temporality in which the past is reproduced, represented and denied, even as it remains a key source of legal and political authority in the face of a fragmenting international order. This temporality is paradoxical, and in this sense, it foreshadows the paradoxes that develop in the House of Commons debate analysed below.

\section{The House of Commons and Global LGBT Rights: Spatio-temporal legacies of empire}

That the queer legacy of colonialism must consider temporalities of empire and coloniality is unsurprising. However, as Valverde insists, temporality is also spatial, and in this respect, the way in which legal actors imagine space and power becomes an important vector of analysis. ${ }^{35}$ In analysing how modern British political/legal actors imagine space, time and power in the context of SOGI, I analyse a single House of Commons debate on Global LGBT Rights from $2017 .^{36}$

The debate was organised by the All Party Parliamentary Group (APPG) on Global LGBT Rights. The APPG was established in 2015 to 'advance LGBT rights around the world' by providing 'a forum for parliamentarians and organisations across the public, private and third sectors to work together to champion LGBT rights and push back against abuse and discrimination'. ${ }^{37}$ The APPG's work thus centres on awareness raising, diplomacy and networking. Its power to legislate - even in the House of Commons - is negligible and it can instead only seek to influence current discourse.

\footnotetext{
${ }^{35}$ Mariana Valverde, Chronotopes of Law: Jurisdiction, Scale and Governance (Abingdon: Routledge, 2015).

36 "Global LGBT Rights" HC Deb 26 October 2017, vol 630, col 515

${ }^{37}$ Kay Lalor and Katherine Browne. 2018 "Here versus There: Creating British Sexual Politics Elsewhere" Feminist Legal Studies 26 no 2 (2018)
} 
In 2018, the APPG was involved in attempts to place LGBT rights on the agenda at the Commonwealth Heads of Government Meeting (CHOGM), hosted by the UK. ${ }^{38}$ This lobbying around LGBT at CHOGM reflects a growing perspective among some political actors, that the UK can and should use its influence within the Commonwealth to secure LGBT rights protections. ${ }^{39}$ As a result, the APPG's backbench debate acts as a microcosm of legal and policy issues relevant to the UK's approach to LGBT issues both at home and elsewhere. By unpicking legal and epistemological structures of the debate, it is possible to centre the way in which outside and inside remain relative and changeable positions within UK law. More simply, inside/outside are not fixed binary identities but positions on a co-constituting continuum. 'Outside' as the space of 'elsewhere', violence or otherness, only exists in relation to 'inside' the as a UK space of safety and tolerance. Exploring these dynamics allows the tracing of how the queer outside exists within UK law.

The backbench debate begins with an explicitly spatial metaphor of a 'Tale of Two Worlds':

This is a tale of two worlds. In one, as we saw in this House, we have seen the near completion of rights for LGBT people, full recognition in law-with some exceptions, of course, throughout the UK — culminating, four years ago, in the passing of same-sex marriage legislation by overwhelming majorities in this House and the other place. In a 16-year period, 25 countries around the world have passed same-sex marriage legislation, while others have passed legislation recognising civil partnerships.

\footnotetext{
38 APPG on LGBT Rights 'Meeting with Foreign Office Minister', APPG December 19, 2017 https://www.appglgbt.org/single-post/2017/12/19/Meeting-with-Foreign-Office-Minister

39 APPG on LGBT Rights 'Parliamentary group on global LGBT rights launches major new inquiry' APPG, July 23, 2015 https://www.appglgbt.org/single-post/2015/07/23/Parliamentary-group-on-global-LGBT-rights-launches-major-new-inquiry
} 
There is another world, too. I am talking about a world in which 75 countries criminalise same-sex activity between consenting adults. That covers 2.9 billion people. Some $40 \%$ of the world's population live in these jurisdictions, which means that more than 400 million people live under laws that punish same-sex activity, and punish it with the death penalty.. ${ }^{40}$

The instinct behind the 'Tale of Two Worlds' is not malicious and does not completely obscure ongoing problems in the UK, but it does unthinkingly reproduce a colonial logic. The previous section highlighted the extent to which the fundamental binary encounter of the coloniser/colonised has shaped legal and political modernity. ${ }^{41}$ This encounter rests on and facilitates a spatial dichotomy of 'here and there' (or inside and outside), a culturalisation of difference, and a civilising mission in which those elsewhere must be 'enlightened'. Weber highlights how in Victorian colonial discourse, figurations of the 'savage', 'primitive', 'colonized' and 'underdeveloped' manifested as sexualized, racialized and perverse. ${ }^{42}$ These figurations persist in modernity and facilitate a paradigm in which the dangerous, feared and other is projected 'elsewhere': a realm that is necessarily anarchic and uncontrolled. Under empire, imperial man required a dangerous, racialized, sexualised savage subject to justify imperial rule. In the current era, this binary persists, but the racialized other is homophobic rather than sexually licentious. ${ }^{43}$ These dynamics are - unintentionally - present in the 'Tale of Two Worlds' and support a binary configuration of sexuality, statehood and sovereignty. As such, the structures of the colonial past are present within the space of the debate, but their ongoing effects are 'unattended'. ${ }^{44}$

\footnotetext{
${ }^{40}$ HC Deb 26 October 2017, vol 630, col 515

${ }^{41}$ Anghie, Imperialism, Sovereignty and the Making of International Law

${ }^{42}$ Cynthia Weber, Queer International Relations: Sovereignty, Sexuality and the Will to Knowledge (Oxford: Oxford University Press, 2016). p.21; Jasbir K. Puar, Terrorist Assemblages: Homonationalism in Queer Times (Durham: Duke University Press, 2007). p.75

${ }^{43}$ Although this homophobic other can also be cast as sexually perverse. See Puar, Terrorist Assemblages

${ }^{44}$ Al-Saji, "Hesitation as Philosophical Method" 
This unacknowledged colonial legacy of cultural differentiation sits alongside a more explicit discomfort with the discussion of empire:

\section{Lloyd Russell-Moyle}

It was the imperial law_combined with our imposition of the imperial Christian religion at the time and expressed by an imperial English language — that enforced the homophobia that still exists in so many of our Commonwealth countries. It was often enforced against the practices and will of the local historical narrative in those countries...

\section{Luke Graham}

The hon. Gentleman is raising a lot of historical points, which is fine, but does he agree that now is the opportunity to use some of our long-standing relationships with these countries to improve those LGBT rights and follow our good example?

\section{Lloyd Russell-Moyle}

That is exactly what I am coming to. I am trying to say that it is our duty to speak up because we were the ones that historically imposed some of these laws. ${ }^{45}$

The exchange above is a forceful illustration of how coloniality structures systems of law and policy, even while the ongoing effects of colonialism are denied ${ }^{46}$ This is a scalar movement that depoliticises the histories of the Commonwealth's origins, but also the broader history of the emergence of international law from the colonial encounter. It invests authority in certain legal and political bodies and invests in these bodies the capacity to determine the 'right' way

\footnotetext{
${ }^{45}$ HC Deb 26 October 2017, vol 630, col 539

${ }^{46}$ Anghie, Imperialism, Sovereignty and the Making of International Law. p.220 
to move forward. ${ }^{47}$ Moreover, depoliticisation permits for a kind of necessary forgetting that allows the past misdeeds of empire to be carefully and completely confined to history. In this relocation of violence, there is a paradox at play: be it the violence of SOGI oppression that is exported overseas, or the horrors of imperial control that is safely confined by the past, the rhetorical structure of the debate allows a distancing that ensures that violence remains in another time and place, even while MPs participate in calling for its end.

\section{Progress and Legal Paradoxes of the Tale of Two Worlds}

The passages discussed in the section above contain an implicit progress narrative typical of LGBTI progress narratives more generally. ${ }^{48}$ In particular, the debate deploys a multiplicity of temporalities that that maintain particular boundaries of inside/outside. 'Elsewhere' or the outside is 'backward' because it has not yet progressed along a teleologically defined path; thus these backward 'others' remain on the 'wrong side of history'. Yet the progressive 'inside' distinguishes itself through a set of ahistorical manoeuvres thorough which the colonial histories, the tools of progress (the law) and the structures through which the categories of inside and outside, are depoliticised and presented as axiomatic, neutral and timeless. ${ }^{49}$

Within the debate the binary separation between the Global North and the Global South is accompanied by an underpinning teleological assumption that those nations who have not yet progressed, must 'catch up' or, as one MP noted, that it 'is up to progressive countries like ours to lead the way in global LGBT rights'.50 This particular comment should not be decontextualized or overplayed - it sits within a larger speech that highlights that the UK needs to 'get its house in order' 51 and address ongoing exclusion, marginalisation and bullying of

\footnotetext{
${ }^{47}$ Mariana Valverde, "Jurisdiction and Scale: Legal 'Technicalities' as Resources for Theory," Social \& Legal Studies 18, no. 2 (2009); Valverde Chronotopes of Law

${ }^{48}$ See particularly Weber, Queer International Relations. p.104-142

${ }^{49}$ Ibid

${ }^{50}$ HC Deb 26 October 2017, vol 630, col 527

${ }^{51}$ Ibid 
LGBTI individuals. What is significant however, is the extent to which such comments emphasise the idea of linear progress towards LGBT Rights 'justice'.

The problematic aspects of linear progress have been scrutinised with reference to human rights law generally ${ }^{52}$, and LGBT rights specifically. ${ }^{53}$ Not only do these narratives maintain already existing hierarchies and modes of legal and political organisation, they also reinforce the power and authority of those who are already deemed to have progressed. In so doing, they often legitimise the - usually legal - tools through which progress has been achieved. This flattens out the specificity of local and national action, universalises (and dematerialises) the material experiences of queer legal realities and presents the (legal) tools of progress as axiomatic, rather than as one possible route towards justice.

Scholarship of law and time has emphasised law's role in producing temporal rhythms, organising time, facilitating linearities, 'emphasizing, erasing, and recasting historical events' ${ }^{54}$ Even the reliance on frameworks of Global LGBT Rights are an enactment of a kind of legal temporality which calls upon the double function of rights as universal and timeless, while also materially embedded and progressively able to realise change. It is striking how much this framework is reflected in the debate:

...we are still on a journey in this country even though we have legislated in many areas, and we have to understand that other countries will also take a long time to get to where we want them to get — they cannot just legislate. We have to use all the tools that are at our disposal, and colleagues on both sides of the House have mentioned some of them. We have soft power that we can exert due to our historical

\footnotetext{
${ }^{52}$ Kathryn McNeilly, "Are Rights out of Time? International Human Rights Law, Temporality, and Radical Social Change," Social \& Legal Studies (2018)

${ }^{53}$ Weber, Queer International Relations

${ }^{54}$ Renisa Mawani, "The Times of Law," Law and Social Inquiry 40, no. 1 (2015). p.261
} 
relationships with many countries, and I hope that we put such issues on the agenda for the upcoming Commonwealth Heads of Government meeting. ${ }^{55}$

The 'necessary forgetting' of empire discussed above is clear in the lack of acknowledgement of the imperial dynamics of the 'historical relationships' in this passage. Here, the journey along the path of (or towards) LGBT rights protections carries with it a duty to use soft power and historical relationships to promote the protection of LGBT rights. A debate that opens by celebrating legal progress thus makes clear the powerlessness of the UK to legislate anywhere outside UK territory, even to repeal laws that were originally written by British colonial administrators. The tools that MPs have available to them are soft law - diplomacy, 'historical relationships' and other forms of non-legal pressure.

This means that while the power of law is venerated as the marker of civilisation and progress in the 'Tale of Two Worlds', UK MPs have few legal tools at their disposal to secure Global LGBT Rights and the 'rational power of law' is ultimately revealed as limited. There is a deeper parallel here with British colonial faith in law reform in its colonies, which nonetheless proceeded 'chaotically and unevenly'56 through a series of experiments that reflected a 'complex and fluid world order with many makers' ${ }^{57}$ In the context of colonial criminalisation of sodomy for example, very similar iterations of criminal penalties can be found in a multiplicity of different legal codes, some of which persist into modernity. But these penalties were externally imposed without reference to different indigenous values or customary law. ${ }^{58}$ Moreover, colonial criminalisations also mark a failure of the rational power of law in Britain itself. During the colonial era, jurists and legal reformers sought to draft and impose a modern, simplified, codified criminal law. ${ }^{59}$ This ultimately failed in Britain, but was imposed -

\footnotetext{
${ }^{55}$ HC Deb 26 October 2017, vol 630, col 530

${ }^{56}$ Benton and Ford, Rage for Order p.6

${ }^{57}$ Ibid

${ }^{58}$ Gupta, "This Alien Legacy"

${ }^{59}$ Kirby, "The Sodomy Offence"
} 
unevenly - in Britain's colonies. Current attempts to bring about decriminalisation - as has occurred within British law - are marked by a failure to reach 'inside' those jurisdictions that retain (or sustain) such laws, even while the structural (and imperially informed) relationship of the Tale of Two Worlds, is maintained.

In this regard, there is a collapse - and a paradox - of the relationship between legal/non-legal and inside/outside. Transnational developments in LGBTI rights may use the language of rights, but are never purely legal, but rather assemblages of law, politics and diplomacy, that cannot be divorced from hierarchies of current and historical power relationships. The 'rational power' of law alone will not secure SOGI justice, nor is it the primary tool of UK MPs seeking Global LGBT Rights, even as they draw upon the UK's own legal progress to justify their engagement with these issues. Moreover, as the section below argues, even as the structure of the debate relies on a framework of inside/outside, MPs own engagement with and imagination of how insider and outsiders are positioned calls this binary framework in to question.

\section{Queer Production of Camaraderie and Kinship}

A key element of the debate is its spatial and temporal expulsion of violence 'elsewhere'. Ironically, the very location of the debate - in the Global North - contributes to the ease within which this expulsion can proceed. Or, as Al-Saji notes when discussing the 'affective weight' of empire:

'Haunting the interstices of the present and structuring its joints, this past is differentially remembered, cognized, and felt by differently positioned subjects. This maps an epistemology of ignorance...by means of which imperial formations and racial imaginaries hide their workings. ${ }^{60}$

\footnotetext{
${ }^{60}$ Al-Saji, "Hesitation as Philosophical Method" p.337
} 
In the context of the debate, the past is carefully positioned and selectively recalled. Ongoing structures of coloniality and modernity - the 'colonial matrix of power' ${ }^{61}$ are disregarded even as they provide the basis upon which the debate takes place. However, simultaneously with this act of spatio-temporal 'forgetting' of colonial violence, MPs also work to emphasise their sense of kinship with LGBTQI communities around the world:

\section{Lloyd Russell Moyle}

Our role is to stand shoulder to shoulder with other LGBT activists - brothers and sisters — around the world and to support them. ${ }^{62}$

\section{Hannah Bardell}

As someone who took until I was 32 to come to terms with my own sexuality, I spent a lot of my early life hiding from myself, my feelings and my emotions, and from the truth of who I am and who I love. But I never, ever had to hide from the state or the police, or out of fear of being persecuted or killed. ${ }^{63}$

\section{Crispin Blunt}

When I say "we", I am thinking of the role that we can play as parliamentarians. We should not underestimate the huge challenge that faces our parliamentary colleagues in other countries that, because of religious beliefs and the influence of religion in those societies, are in the same state as the United Kingdom in the 1950s when it comes to attitudes to LGBT people. ${ }^{64}$

\footnotetext{
${ }^{61}$ Mignolo. ""Decoloniality and Phenomenology"; Mignolo "Global Coloniality and the World Disorder"

${ }^{62}$ HC Deb 26 October 2017, vol 630, col 540

${ }^{63}$ Ibid col 534

${ }^{64}$ Ibid col 526
} 


\section{Nigel Evans}

Growing up in Swansea, I wondered whether it was braver of me to come out as a Conservative or gay. I have tried both and it does not seem to have done me any harm. ${ }^{65}$

Thus, legal and political cleavages that re-inscribe dynamics of Global North/Global South, civilised/uncivilised are undercut by claimed personal connections with LGBTQI individuals elsewhere.

The point here is not to dismiss genuinely felt connections with LGBTQI people elsewhere in the world, or to suggest that a shared sense of kinship cannot exist. But it is significant that even while violence is expelled 'elsewhere', a sense of kinship and connection is maintained. The debate only makes sense if the suffering queer is both 'here and there', 'inside and outside', within the framework of the debate. Through these rhetorical moves, Global Southern SOGI subjects - both real and imagined - are compelled to represent both the closeness of shared identity and the distance of structural violence, in a manoeuvre in which both upsets and maintains logics of inside and outside.

The simultaneous closeness and distance also reveals the jurisdictional struggle over Global Southern LGBTI individuals, and the lack of power these individuals often have in responding to this struggle. ${ }^{66}$ Such individuals are metaphorically and legally 'stretched' across different locations, as they are claimed as subjects by multiple legal and regulatory systems - domestic, foreign, international and transnational. The tensions of this position are myriad, spatiotemporally specific and sometimes dangerous. ${ }^{67}$ However, it can also be suggested that this

\footnotetext{
${ }^{65}$ Ibid col 521

${ }^{66}$ See Valverde Chronotopes of Law for a discussion of how these struggles are often depoliticised.

${ }^{67}$ See Adrian Jjuuko and Fridah Mutesi, "The Multifaceted Struggle against the Anti-Homosexuality Act in Uganda," in Envisioning Global Lgbt Human Rights: (Neo)Colonialism, Neoliberalism, Resistance and Hope, ed. Nancy Nicol, et al. (London Institute of Commonwealth Studies, 2018) and Adrian Jjuuko, "International Solidarity and Its Role in the Fight 
positioning across multiple legal fields creates possibilities for strategies that draw attention to, challenge and upend accepted structural binaries and thus 'undermine the dichotomy between colonizer and colonized, self and other on which the civilizing mission is based. ${ }^{68}$ The reality however, is often that the vast diversity and contingency of sexual and gender identity and experience is reified, flattened and dominated by those who are most visible and powerful, or most able to engage with Western power brokers. ${ }^{69}$ The MPs at the debate were clearly aware of this problematic dynamic, but this awareness does not negate the fact that to become visible in the debate, queer subjects had to become part of British MPs' stories.

The central role of the politics of affect and of visibility in the debate is not surprising. ${ }^{70}$ What is striking however, is the deployment of emotion and visibility in the production of unanimity and consensus. The MPs quoted above come from different political parties and have generally adopted wildly different policy positions. Yet within this particular debate, the normally antagonistic House of Commons was remarkably collegiate:

It is right that across the House, on an entirely non-partisan basis... We have sent a signal today - and I am grateful that both Her Majesty's Opposition and the

\footnotetext{
against Uganda's Anti-Homosexuality Bill," in Gender, Sexuality and Social Justice: What's Law Got to Do with It?, ed. Kay Lalor, et al. (Institute of Development Studies, 2016) for a discussion of these tensions in Uganda. Other texts in this collection discuss similar tensions in different contexts.

${ }^{68}$ Anghie, Imperialism, Sovereignty and the Making of International Law p.319. Ugandan activists did this in the case of Sexual Minorities Uganda $v$ Scott Lively Civil Action 3:12-CV-30051 (MAP) (US District Court for the District of Massachusetts). See Kay Lalor, "Encountering the Past: Grand Narratives, Fragmented Histories and LGBTI Rights 'Progress'," Law and Critique 30, no. 1 (2019).

${ }^{69}$ Phillip M. Ayoub and David Paternotte, eds., LGBT Activism and the Making of Europe: A Rainbow Europe? (Basingstoke: Palgrave MacMillan, 2014). p.15

${ }^{70}$ Emotion/affect and visibility have played an important role in queer politics. On queer affect see Sally R. Munt, Queer Attachments: The Cultural Politics of Shame (Aldershot: Ashgate, 2007); Senthorun Raj, "A/Effective Adjudications: Queer Refugees and the Law," Journal of Intercultural Studies 38, no. 4 (2017). On queer visibility see e.g. Ashley Currier, "Behind the Mask: Developing LGBTI Visibility in Africa," in Development, Sexual Rights and Global Governance, ed. Amy Lind (London: Routledge, 2010); Eve Kosofsky Sedgwick, The Epistemology of the Closet (Hemel Hempstead: Harvester Wheatsheaf, 1991); Andrew Gorman-Murray and Catherine J. Nash, "LGBT Communities, Identities and the Politics of Mobility: Moving from Visibility to Recognition in Contemporary Urban Landscapes," in The Routledge Research Companion to Geographies of Sex and Sexuality, ed. Gavin Brown and Kath Browne (London: Routledge, 2016).
} 
Government have reinforced that signal — that abuses of LGBT rights cannot be tolerated. $^{71}$

The camaraderie of the debate, and the forms of kinship that it imagines, reproduces in microcosm the 'Tale of Two Worlds'. Unanimity is made possible through its binary relationship with the violent other. There is broad agreement on the deeper structural and epistemological questions that are brought in to play (but not named) in the course of the debate: law facilitates progress, progress is relatively linear, those who have progressed have a duty to assist elsewhere, and empire is firmly confined to the past. The situation in the UK may not be perfect, but it is progressing in the right direction, and problems are a matter of individual violence rather than overarching structural or 'cultural' factors.

This is why one of the few interventions that challenged these narratives was so striking. Rather than drawing on her personal experiences, Joanna Cherry, MP contacted a campaigning organisation for guidance on which issues to raise. The outcome highlighted the UK's treatment of LGBT asylum seekers:

If we in the United Kingdom want to promote ourselves as supportive of LGBT+ rights and if we want to stand here and criticise other countries that are not, we must, across the parties, tackle the disgraceful treatment that some LGBTI+ asylum seekers and refugees receive in the United Kingdom. ${ }^{72}$

Cherry makes visible those LGBTI+ bodies that disrupt and challenge comfortable assumptions that despite individual instances of violence, the UK is on the right path especially with respect to its law. She emphasises a structural failure in UK law that traps SOGI asylum seekers figuratively within bureaucratic mazes and literally within detention centres.

\footnotetext{
${ }^{71}$ HC Deb 26 October 2017, vol 630, col 548

${ }^{72}$ Ibid col 542-543 
Implicit here is a demand we acknowledge that if queer people are indeed kin, then we have failed them, not just in the safely distant days of empire, but in the immediate present. Cherry's intervention is notable in that it demands concrete and achievable action within the UK, but in so doing, it must necessarily maintain a binary of inside/outside. The call for asylum protections for those coming to the UK from elsewhere holds to the narrative of the legally regulated inside and dangerous outside. The disruption that she presents is to the effectiveness of UK law in offering protection to those 'others' who seek sanctuary here. ${ }^{73}$ The challenge is to go beyond this intervention to face the underpinning paradoxes within which the queer legacy of colonialism starts to emerge. It is to this challenge that the final section of this chapter turns.

\section{Exposing Queer Paradoxes within Legal Institutions}

The aim of this chapter is not to dismiss or ridicule the clearly deeply felt desire to improve the situations of LGBTQI individuals and groups worldwide. There is value, however, in considering 'how we come to understand ourselves as subjects of various legal regimes, how certain things come to be governed, how certain disciplinary and regulatory knowledges and practices congeal into institutional forms' ${ }^{74}$ The sections above considered how practices of coloniality congeal in institutional and paradoxical forms within British law and government. To take these paradoxes seriously is to view them not as contradictions that can be easily resolved, but as a framework that can be used to expose queer legacies of colonialism in UK law and how the unacknowledged presence of coloniality within UK legal processes inhibit the possibility of more far reaching action to secure SOGI justice.

In this context, Deleuzian scholarship of paradox is particularly useful:

\footnotetext{
73 Thank you to Kath Browne and Sen Raj for helpful comments on this point.

${ }^{74}$ Dean Spade, "Laws as Tactics," Columbia Journal of Gender and the Law 21, no. 2 (2012). p.41 
“...paradoxes have a two-fold function... On the one hand, they have a critical function demonstrating the limits of given claims and positions, most often those based on common sense and on hidden presuppositions about identities. On the other hand, paradoxes have a generative function, that is, the paradox generates a problem which itself leads to a series of speculative partial solutions, where partial means the problem recurs but is transformed'. ${ }^{75}$

The first form of paradox is present in the debate- there is much discussion of violence suffered by LGBTQI individuals overseas, but the solutions offered are limited and contradictory. Temporally, spatially and legally, the UK remains trapped. In facing violence 'elsewhere', UK politicians either turn to past relations and forms of power, or project onto the spaces of 'elsewhere' the legal solutions through which the UK has 'progressed'. They engage in the 'ritual application of human rights principles' in a way that universalises, dematerialises and abstracts specific situations and problems. ${ }^{76}$ As such, the debate begins with an already established solution to a perceived problem ${ }^{77}$ - the 'Tale of Two Worlds' emphasises LGBT rights, legal progress and legislative solutions to LGBTQI suffering. This means that problems experienced by LGBTQI individuals must always be understood in such a way as to fit with this already established, rights-based solutions.

In this sense, the legal solutions offered and the conceptual foundations upon which they rest are insufficient to the task of responding to questions of SOGI injustice. Moreover, while within the House of Commons, the UK's leadership and national identity as enlightened and progressive may be celebrated, elsewhere in the world, where the weight of empire is heavier,

\footnotetext{
${ }^{75}$ James Williams, Gilles Deleuze's Philosophy of Time: A Critical Introduction and Guide (Edinburgh: Edinburgh University Press, 2011). p.52; See also Gilles Deleuze, The Logic of Sense, ed. Constantin V. Boundas, trans. M. Lester and C. Stivale (London: Continuum, 2004). p.3

${ }^{76}$ Gilles Deleuze, "On Human Rights" L'Abécédaire de Gilles Deleuze, avec Claire Parnet. Video edited Montparnasse, 1996 http://www.generation-online.org/p/fpdeleuze10.htm.

${ }^{77}$ Gilles Deleuze, Bergsonism, trans. Hugh Tomlinson and Barbara Habberjam (New York: Zone Books, 1991) p.16; Gilles Deleuze, Difference and Repetition, trans. P Patton (London: Continuum, 2011) p.201.
} 
this dynamic operates very differently. Public interventions by UK authorities into the treatment of LGBT subjects in former colonies have been met with considerable backlash in recent years. ${ }^{78}$ Moreover, in some recent cases in which colonial era laws have been challenged or overturned, there is a sense of an elision of decriminalisation with decolonisation. In this regard, the recent Indian Supreme Court judgment Navtej Johar v Union of India is worth quoting at length:

A hundred and fifty eight years ago, a colonial legislature made it criminal, even for consenting adults of the same gender, to find fulfilment in love. The law deprived them of the simple right as human beings to live, love and partner as nature made them. The human instinct to love was caged by constraining the physical manifestation of their sexuality. Gays and lesbians were made subordinate to the authority of a coercive state. A charter of morality made their relationships hateful. The criminal law became a willing instrument of repression. To engage in 'carnal intercourse' against 'the order of nature' risked being tucked away for ten years in a jail. The offence would be investigated by searching the most intimate of spaces to find tell-tale signs of intercourse. Civilisation has been brutal. ${ }^{79}$

Here, the Indian Supreme Court creates a 'Tale of Two Worlds' where the UK represents a cruel colonial past from which India must depart.

The debate around SOGI in India is not just one of decoloniality - it confronts sexuality, gender, decriminalisation, patriarchy, class and caste, among others. ${ }^{80}$ The point in presenting

\footnotetext{
78 BBC News 'Uganda fury at David Cameron aid threat over gay rights' $B B C$ News, Oct 31, https://www.bbc.co.uk/news/world-africa-15524013

${ }^{79}$ Writ Petition (Criminal) No.76/2016 at 2

${ }^{80}$ Siddharth Mohansingh Akali, "Learning from Suresh Kumar Koushal V. Naz Foundation through Introspection, Inclusion, and Intersectionality: Suggestions from within Indian Queer Justice Movements," Berkeley Journal of Gender, Law and Justice 31, no. 1 (2016); Aniruddha Dutta, "Contradictory Tendencies: The Supreme Court's Nalsa Judgment on Transgender Recognition and Rights," Journal of Indian Law and Society 5 (2014); Vikram Raghavan, "Navigating the Noteworthy and Nebulous in Naz," in Law Like Love, ed. Arvind Narrain and Alok Gupta (New Delhi: Yoda Press, 2011).; Semmalar, Imaan "Gender Outlawed: The Supreme Court Judgment on Third Gender and Its Implications", Round Table India, April 19, 2014
} 
this small legal snapshot however, is question whether the UK can offer anything to this Indian debate, other than to be a representative of a colonial past that continues to structure dynamics of oppression in the present. Navtej Johar could be taken as an example of the kind of legal progress celebrated in the House of Commons, but the UK debate cannot or will not engage fully with the present reality of coloniality. As such, the solutions that it offers in the form of the progressive advancement of legal inclusion of LGBTQI subjects is rendered less powerful by its refusal to acknowledge the extent to which 'civilization has been brutal'.

It is important not to overstate the UK's powerlessness: India is just one example of how a Commonwealth state has responded to British anti-sodomy laws in recent years. And beyond pure legal paradigms, the UK has been able to offer aid - be it through quiet diplomatic support, training or financing projects that have helped LGBTQI groups. ${ }^{81}$ Some UK groups have been able to offer legal support in certain circumstances. ${ }^{82}$ It is noticeable however that these actions are often ad hoc, acts of quiet diplomacy, or undertaken in response to requests from groups in the Global South. The UK can act to support LGBT rights, but in a way that is fractured, reactive and multi-directional.

There is therefore a structural contradiction at the heart of the House of Commons debate. The paradoxes here are not a minor impasses or easily resolvable misunderstandings, but products of an inherently flawed system. Bruce-Jones argues that there is a certain comfort in ignoring the flaws of the system within which we work as it 'allows us to focus on the "positive"... to defer to the current system, as it unarguably saves lives while politically viable alternatives are

\footnotetext{
http://roundtableindia.co.in/index.php?option=com content\&view=article\&id=7377:because-we-have-a-voice-too-thesupreme-court-judgment-on-third-gender-and-its-implications\&catid=120:gender\&Itemid=133

${ }^{81}$ Foreign and Commonwealth Office 'An FCO programme for promoting the human rights of LGBT people London. 2010; Government Equalities Office Policy paper: LGBT Action Plan 2018: Improving the lives of Lesbian, Gay, Bisexual and Transgender people London. 2018.

82 Jjuuko and Mutesi, "The Multifaceted Struggle against the Anti-Homosexuality Act in Uganda," 
curtailed' ${ }^{83}$ Something similar is present in the House of Commons debate and within UK approaches to Global LGBT rights more generally. There is comfort to be found in using the tools that we have - however limited - to try to respond to violence and injustice. The queer legacy of colonialism in UK law however, is that paradox breaks through, whether it is acknowledged or not. The linear, 'common sense', progressive arguments of the debate are interrupted by the un-thought or unsaid presence of coloniality - the 'excess' without which the debate would collapse into incoherence. ${ }^{84}$

This is why an approach that uses queerness to expose how the 'normal' is 'contingent, constituted and open to change ${ }^{85}$ is necessary. This approach involves acknowledging the second aspect of Deleuze's paradox - as generative of new and creative solutions to problems. Yet by acknowledging the paradoxes at the heart of the debate, we must also then acknowledge that these paradoxes support a number of other associated truisms that are then called in to question. ${ }^{86}$ To do this would be to challenge all that has been achieved so far, because it asks the question of what a queer justice would look like outside the framework of colonial binaries, civilising missions, the legal production of justice, and stable sexual and gendered identities. It would open up the blind spots in the UK narrative of progress in a way that goes far beyond Cherry's intervention on LGBT asylum, and instead call into question the conceptual and structural foundations of our political and legal orderings.

What would be required here is a process that replays or re-works our assumptions in a way that calls those assumptions into question. To do this is to fully feel the weight of the colonial past and to challenge the imperial structures that animate our present. A queer approach in this case would require attentiveness to temporality in a way that challenged spatial paradigms of

\footnotetext{
${ }^{83}$ Eddie Bruce-Jones, "Death Zones, Comfort Zones: Queering the Refugee Question," International Journal of Minority and Group Rights 22, no. 1 (2015). p.109

${ }^{84}$ Rosi Braidotti, Transpositions (Cambridge: Polity, 2006). p.174; Deleuze The Logic of Sense p.78

${ }^{85}$ Colebrook, "On the Very Possibility of Queer Theory," p.21

${ }^{86}$ Thanks to Mark James for this formulation.
} 
inside and outside. It is one that would acknowledge the fluidity of the 'Tale of Two Worlds' and the extent to which stable binaries of cultural or legal difference are ultimately restrictive and limited. It would strengthen our awareness of interconnection with others not just as a duty to help individuals elsewhere to 'catch up', but as a responsibility to participate in dismantling global hierarchies. ${ }^{87}$ Such a practice is compelled to face the way that violence exists within those spaces that are deemed safe and thus renders irrelevant the spatial binary of the Two Worlds. ${ }^{88}$ Similarly it challenges what El-Enany terms "legal idolatry" - a belief in the power of rights to bring justice, that does not recognise the administrative and biopolitical dimension of rights for managing disenfranchised populations. ${ }^{89}$ It would also be open to the precarity of the way in which 'the transnational legal sphere is characterized by the coexistence of multiple legal orders and regimes ${ }^{90}$, and to the limitations of an international system that has not escaped its foundations in the colonial encounter.

There is a vulnerability to this position - it involves acknowledgement that the future may be significantly different to the past and that expected trajectories of progress cannot be relied upon. It requires that the weight of empire be felt more fully. The irony however, is that these questions and challenges are not inserted into UK law from elsewhere. The queer legacy of colonialism in UK law is that there is no 'queer outside' - queerness sits within UK law as a Deleuzian paradox or 'aleatory point' that brings connection and meaning amidst disjunction or even nonsense. ${ }^{91}$ Queerness here is an exposure of limitations, and a challenge to re-work those limitations into new solutions. To do this means revisiting the painful legacy of

\footnotetext{
${ }^{87}$ Rosi Braidotti, "On Putting the Active Back into Activism," New Formations 68 (2009).

${ }^{88}$ Bruce-Jones, "Death Zones, Comfort Zones"

${ }^{89}$ Nadine El-Enany, "On Pragmatism and Legal Idolatry: Fortress Europe and the Desertion of the Refugee Special Issue: Critical Approaches to Migration Law," International Journal on Minority and Group Rights 22, no. 1 (2015).

${ }^{90}$ Burchardt, "Intertwinement of Legal Spaces in the Transnational Legal Sphere" p.305

${ }^{91}$ Deleuze, The Logic of Sense
} 
colonialism and coloniality in UK law and addressing that legacy, not as a self-contained past, but as an ongoing present.

\section{Conclusion}

While this chapter has focused on a debate on Global LGBT rights, it offers a perspective on queer legacies of colonialism that goes far beyond questions of gender and sexuality. The legacy of colonialism in UK law is present in our legal orderings, our relations with and perceptions of the rest of the world, and in our construction of our national identity. In the queer Deleuzian reading advanced in the final part of this chapter, a queer legacy of colonialism is one that demands that we re-work these orderings, identities and relationships in a way that challenges that which is taken as axiomatic and more fully acknowledges the weight of the past. In the simplest terms, this was never a tale of two worlds, and the ongoing attachment to this framing and its associated spatio-temporal assumptions, obscures the more complex paradoxes at play, and thus the possibility of more far-reaching change.

Thus an analysis of the APPG's approach to Global LGBT rights in its backbench debate suggests that it is inherently paradoxical, but an engagement with these paradoxes can be productive. In this respect, there is no queer outside to our colonial legacy in UK law: queerness sits within, unacknowledged and sometimes un-thought, but a necessary presence that gives sense to contradictory positions. To confront that queer paradox is to give up our sense of legal certainty, knowledge and progress, and to think beyond the framework of the state, identity and law. This is not necessarily something that members of the APPG on LGBT Rights would be comfortable doing, but to ignore the queer, paradoxical heart of the debate does not make it disappear - it remains, as a contradiction. It offers insight into how we might proceed, but makes no secret of the scope of the task. As such, the fact that a House of Commons debate on 
Global LGBT rights is necessarily paradoxical is no surprise. Whether we can face this paradox remains as an unspoken challenge. 


\section{References}

Akali, Siddharth Mohansingh. "Learning from Suresh Kumar Koushal V. Naz Foundation through Introspection, Inclusion, and Intersectionality: Suggestions from within Indian Queer Justice Movements." Berkeley Journal of Gender, Law and Justice 31, no. 1 (2016): 121-82.

Al-Saji, Alia. "SPEP Co-Director's Address: Hesitation as Philosophical Method-Travel Bans, Colonial Durations, and the Affective Weight of the Past." The Journal of Speculative Philosophy 32, no. 3 (2018): 331-59.

Anghie, Antony. Imperialism, Sovereignty and the Making of International Law. Cambridge: Cambridge University Press, 2007.

APPG on LGBT Rights 'Parliamentary group on global LGBT rights launches major new inquiry' APPG, July 23, 2015 https://www.appglgbt.org/single-post/2015/07/23/Parliamentary-groupon-global-LGBT-rights-launches-major-new-inquiry

APPG on LGBT Rights 'Meeting with Foreign Office Minister', APPG December 19, 2017 https://www.appglgbt.org/single-post/2017/12/19/Meeting-with-Foreign-Office-Minister

Ayoub, Phillip M., and David Paternotte, eds. LGBT Actiism and the Making of Europe: A Rainbow Europe? Basingstoke: Palgrave MacMillan, 2014.

BBC News 'Uganda fury at David Cameron aid threat over gay rights' $B B C$ News, Oct 31, https://www.bbc.co.uk/news/world-africa-15524013

Benton, Lauren, and Lisa Ford. Rage for Order the British Empire and the Origins of International Law, 1800-1850. Cambridge, MA.: Harvard University Press, 2016.

Braidotti, Rosi. Transpositions. Cambridge: Polity, 2006.

Braidotti, Rosi. "On Putting the Active Back into Activism." New Formations 68 (2009).

Bruce-Jones, Eddie. "Death Zones, Comfort Zones: Queering the Refugee Question." International Journal of Minority and Group Rights 22, no. 1 (2015): 101.

Burchardt, Dana. "Intertwinement of Legal Spaces in the Transnational Legal Sphere." Leiden Journal of International Law 30, no. 2 (2017): 305-26.

Colebrook, Claire. "On the Very Possibility of Queer Theory." In Deleuze and Queer Theory, edited by Chrysanthi Nigianni and Merl Storr. Edinburgh: Edinburgh University Press, 2009. . "Queer Vitalism." New Formations 68 (2010).

Connell, Raewyn. Southern Theory. Cambridge: Polity, 2007.

Crerar, Pippa. "Theresa May Says She Deeply Regrets Britain's Legacy of Anti-Gay Laws." The Guardian, 17 April 2018.

Currah, Paisley. "The State." TSQ: Transgender Studies Quarterly 1, no. 1-2 (2014): 197-200.

Currier, Ashley. "Behind the Mask: Developing LGBTI Visibility in Africa." In Development, Sexual Rights and Global Governance, edited by Amy Lind. London: Routledge, 2010.

Deleuze, Gilles. Difference and Repetition. Translated by P Patton. London: Continuum, 2011. 1968.

- The Logic of Sense. Translated by M. Lester and C. Stivale. Edited by Constantin V. Boundas London: Continuum, 2004. 1969.

."On Human Rights" L'Abécédaire de Gilles Deleuze, avec Claire Parnet. Video edited Montparnasse, 1996 http://www.generation-online.org/p/fpdeleuze10.htm.

. Bergsonism. Translated by Hugh Tomlinson and Barbara Habberjam. New York: Zone Books, 1991.

Dutta, Aniruddha. "Contradictory Tendencies: The Supreme Court's Nalsa Judgment on Transgender Recognition and Rights." Journal of Indian Law and Society 5 (2014): 225-36.

El-Enany, Nadine. "On Pragmatism and Legal Idolatry: Fortress Europe and the Desertion of the Refugee Special Issue: Critical Approaches to Migration Law.". International Journal on Minority and Group Rights 22, no. 1 (2015): 7-38.

El-Enany, Nadine. "Things Fall Apart: From Empire to Brexit Britain” IPR Blog, May 2nd 2017 http://blogs.bath.ac.uk/iprblog/2017/05/02/things-fall-apart-from-empire-to-brexit-britain/

Eslava, Luis. "Istanbul Vignettes: Observing the Everyday Operation of International Law." London Review of International Law 2, no. 1 (2014): 3-47.

Eslava, Luis. Local Space, Global Life: The Everyday Operation of International Law and Development. Cambridge: Cambridge University Press, 2015. 
Fanon, Frantz. Black Skin, White Masks. London: Pluto, 1986. 1952.

Gopal, Priyamvada. "Redressing Anti-Imperial Amnesia." Race \& Class 57, no. 3 (2016): 18-30.

Gorman-Murray, Andrew, and Catherine J. Nash. "LGBT Communities, Identities and the Politics of Mobility: Moving from Visibility to Recognition in Contemporary Urban Landscapes." In The Routledge Research Companion to Geographies of Sex and Sexuality, edited by Gavin Brown and Kath Browne. London: Routledge, 2016.

Greenhouse, Carol J. "Nationalizing the Local: Comparative Notes on the Recent Restructuring of Political Space." In Human Rights in the 'War on Terror', edited by Richard Ashby Wilson. Cambridge: Cambridge University Press, 2005

Grosfoguel, Ramón. "The Epistemic Decolonial Turn." Cultural Studies 21, no. 2-3 (2007): 211-23.

Gupta, Alok. "This Alien Legacy the Origins of "Sodomy" Laws in British Colonialism." edited by Human Rights Watch, 2008.

Howe, Stephen. "Internal Decolonization? British Politics since Thatcher as Post-Colonial Trauma." Twentieth Century British History 14, no. 3 (2003): 286-304.

James, Mark, and Guy Osborn. "The Olympics, Transnational Law and Legal Transplants: The International Olympic Committee, Ambush Marketing and Ticket Touting." Legal Studies 36, no. 1 (2016): 93-110.

Jjuuko, Adrian. "International Solidarity and Its Role in the Fight against Uganda's Anti-Homosexuality Bill." In Gender, Sexuality and Social Justice: What's Law Got to Do with It?, edited by Kay Lalor, Elizabeth Mills, Arturo Sánchez García and Polly Haste: Institute of Development Studies, 2016.

Jjuuko, Adrian, and Fridah Mutesi. "The Multifaceted Struggle against the Anti-Homosexuality Act in Uganda." In Envisioning Global Lgbt Human Rights: (Neo)Colonialism, Neoliberalism, Resistance and Hope, edited by Nancy Nicol, Adrian Jjuuko, Richard Lusimbo and Nick J. Mulé. London Institute of Commonwealth Studies, 2018.

Kirby, Michael. "The Sodomy Offence: England's Least Lovely Criminal Law Export?". In Human Rights, Sexual Orientation and Gender Identity in the Commonwealth: Struggles for Decriminalisation and Change, edited by Corinne Lennox and Matthew Waites: Institute of Commonwealth Studies, 2013.

Kneen, B. The Tyranny of Rights. Ottowa: The Ram's Horn, 2009.

Lalor, Kay. "Encountering the Past: Grand Narratives, Fragmented Histories and Lgbti Rights 'Progress'." Law and Critique 30, no. 1 (April 01 2019): 21-40.

Lalor, Kay and Katherine Browne. 2018 "Here versus There: Creating British Sexual Politics Elswhere" Feminist Legal Studies 26 (2): 205-213.

Mawani, Renisa. "The Times of Law." Law and Social Inquiry 40, no. 1 (2015): 253-63.

McClintock, Anne. Imperial Leather: Race, Gender and Sexuality in the Colonial Contest. London: Routledge, 1995.

McNeilly, Kathryn. "Are Rights out of Time? International Human Rights Law, Temporality, and Radical Social Change." Social \& Legal Studies (December 2018). doi:10.1177/0964663918815729.

Mgbeoji, Ikechi. "The Civilised Self and the Barbaric Other: Imperial Delusions of Order and the Challenges of Human Security." Third World Quarterly 27, no. 5 (2006): 855-69.

Michaels, Ralf. "Globalisation and Law: Law Beyond the State ". In Law and Social Theory edited by Reza Banakar and Max Travers. Oxford: Hart, 2013.

Mignolo, Walter D. "Global Coloniality and the World Disorder: Decoloniality after Decolonization and Dewesternization after the Cold War." World Public Forum "Dialogue of Civilizations" (2016).

http://wpfdc.org/images/2016_blog/W.Mignolo_Decoloniality_after_Decolonization_Dewest ernization_after_the_Cold_War.pdf.

Mignolo, Walter D. "Decoloniality and Phenomenology: The Geopolitics of Knowing and Epistemic/Ontological Colonial Differences.". The Journal of Speculative Philosophy 32, no. 3 (2018): 360-87.

Mukherjee, Aditya. "Empire: How Colonial India Made Modern Britain." Economic and Political Weekly 45, no. 50 (2010): 73-82.

Munt, Sally R. Queer Attachments: The Cultural Politics of Shame. Aldershot: Ashgate, 2007. 
Ong, Aihwa. "(Re)Articulations of Citizenship." PS: Political Science and Politics 38, no. 4 (2005) (2005): 697-99.

Porter, Bernard. "Further Thoughts on Imperial Absent-Mindedness." The Journal of Imperial and Commonwealth History 36, no. 1 (2008): 101-17.

Price, Richard. "One Big Thing: Britain, Its Empire, and Their Imperial Culture." Journal of British Studies 45, no. 3 (2006): 602-27.

Puar, Jasbir K. Terrorist Assemblages: Homonationalism in Queer Times. Durham: Duke University Press, 2007.

Raghavan, Vikram. "Navigating the Noteworthy and Nebulous in Naz." In Law Like Love, edited by Arvind Narrain and Alok Gupta. New Delhi: Yoda Press, 2011.

Raj, Senthorun. "A/Effective Adjudications: Queer Refugees and the Law." Journal of Intercultural Studies 38, no. 4 (2017): 453-68.

Rajagopal, Balakrishnan. "Counter-Hegemonic International Law: Rethinking Human Rights and Development as a Third World Strategy." Third World Quarterly 27, no. 5 (2006): 767-83.

Sedgwick, Eve Kosofsky. The Epistemology of the Closet. Hemel Hempstead: Harvester Wheatsheaf, 1991.

Semmalar, Imaan "Gender Outlawed: The Supreme Court Judgment on Third Gender and Its Implications", Round Table India, April 19,2014 http://roundtableindia.co.in/index.php?option=com content\&view=article\&id=7377:becausewe-have-a-voice-too-the-supreme-court-judgment-on-third-gender-and-itsimplications\&catid=120: gender\&Itemid $=133$

Spade, Dean. "Laws as Tactics." Columbia Journal of Gender and the Law 21, no. 2 (2012): 40-71.

Valverde, Mariana. Chronotopes of Law: Jurisdiction, Scale and Governance. Abingdon: Routledge, 2015.

. "Jurisdiction and Scale: Legal 'Technicalities' as Resources for Theory." Social \& Legal Studies 18, no. 2 (2009): 139-57.

Ward, Stuart, ed. British Culture and the End of Empire. Manchester: Manchester University Press, 2001.

Weber, Cynthia. Queer International Relations: Sovereignty, Sexuality and the Will to Knowledge. Oxford: Oxford University Press, 2016.

Williams, James. Gilles Deleuze's Philosophy of Time: A Critical Introduction and Guide. Edinburgh: Edinburgh University Press, 2011.

Zumbansen, Peer. "How, Where and for Whom? Interrogating Law's Forms, Locations and Purposes." In Legal Studies Research Paper Series, edited by Dayan Farias Picon: Kings College London Dickson Poon School of Law, 2016. 